\title{
Winter bloom of the diatom Nitzschia delicatula in the open waters of the Black Sea
}

\author{
A. S. Mikaelyan* \\ P. P. Shirshov Institute of Oceanology, Russian Academy of Sciences, 23 Krasikova St., Moscow, 117851, Russia
}

\begin{abstract}
Spatial distribution, cell division and cellular chlorophyll content were studied in populations of the diatom Nitzschia delicatula Hasle during the winter phytoplankton bloom in open waters of the Black Sea in 1991. This diatom contributed 39 to $87 \%$ (mean $72 \%$ ) to phytoplankton biomass. Cell numbers were as high as $6 \times 10^{9}$ cells $\mathrm{m}^{-3}$ and biomass was as high as $2.7 \mathrm{~g} \mathrm{~m}^{-3}$ The frequency of dividing cells in the population varied from 0 to $37 \%$. A diurnal rhythm in cell division was not observed. Production of $N$. delicatula was estimated from carbon biomass and the percentage of dividing cells in the population. High values of carbon biomass ( 3 to $5 \mathrm{~g} \mathrm{C} \mathrm{m}^{-2}$ ), production $\left(1\right.$ to $\left.3 \mathrm{~g} \mathrm{C} \mathrm{m}^{-2} \mathrm{~d}^{-1}\right)$ and daily $P / B$ coefficients $(0.5$ to 0.8$)$ indicated the active growth of the population in the central parts of the western and eastern cyclonic gyres. On average, for phytoplankton communities predominantly made up of $N$. delicatula, estimated production was 2.3 tımes as high as primary production measured by the ${ }^{14} \mathrm{C}$ technique. Vertical changes of chlorophyll cell content were used as an index of the mixing in phytoplankton assemblages. While phytoplankton biomass was inversely related to the mixed layer depth, population growth rate depended upon mixing activity in the upper water column.
\end{abstract}

KEY WORDS: Phytoplankton Black Sea Winter bloom Cell division - Photoadaptation

\section{INTRODUCTION}

An unusual situation occurs in the open areas of the Black Sea in winter: active upwelling of deep waters to the surface layer occurs in the central parts of the western and eastern main cyclonic gyres (see Fig. 1). With the absence of the seasonal thermocline, the upper margin of the main pycnocline is located at depths of 20 to $30 \mathrm{~m}$, while on the periphery of the gyres this margin is at depths of 50 to $100 \mathrm{~m}$ and deeper (Ovchinnikov \& Popov 1990). As a result, high values of phytoplankton abundance and primary production are observed (Krupatkina et al. 1991, Sukhanova et al. 1991a).

The diatom Nitzschia delicatula Hasle occurs in the Black Sea both in coastal (Zernova 1981) and offshore open waters (Ratkova et al. 1989). Most studies of phytoplankton in the Black Sea have been conducted by means of light microscopy, with which it is virtually impossible to distinguish $N$. delicatula from $N$. delicatissima $\mathrm{Cl}$. Since the time of its first mention by

•E-mail: Iafepo@mx.iki.rssi.ru
Morozova-Vodyanitskaya (1954) $N$. delicatissima has been constantly presented in species lists for all parts of the Black Sea (Belogorskaya \& Kondratieva 1965 , Ivanov 1965, Sukhanova \& Belyaeva 1980, Nezlin \& Zernova 1983, Sukhanova et al. 1987, 1991a). Both species (denoted below as Nitzschia spp.) occur in phytoplankton populations throughout the year, although their abundance reaches a maximum in winter

The winter bloom of diatoms, including Nitzschia spp., was reported first by Belogorskaya \& Kondratieva (1965). Limited data on interannual changes in phytoplankton standing stock obtained in the eastern Black Sea between 1961 and 1976 also showed a phytoplankton biomass maximum in February-March (Mashtakova \& Roukhiyainen 1979). The highest cell numbers of Nitzschia spp. were observed at the centers of the 2 main cyclonic gyres in March 1988, during the last stage of the diatom bloom (Sukhanova et al. 1991a). Cell numbers and biomass were as high as $4.5 \times 10^{9}$ cells m$^{-3}$ and $1.2 \mathrm{~g} \mathrm{~m}^{-3}$, respectively. After the appearance of the seasonal pycnocline, accumulations of diatom cells have been observed below the upper 
mixed layer (Morozova-Vodyanitskaya 1954, Belogorskaya \& Kondratieva 1965, Sukhanova et al. 1987). Observations made from the submersible 'Argus' have also shown that these accumulations occupy a narrow layer 3 to $5 \mathrm{~m}$ below the seasonal pycnocline. Cell numbers and biomass of Nitzschia delicatula (electron microscopic determination) in this layer in May-June 1986 were as high as $0.3 \times 10^{9}$ cells $\mathrm{m}^{-3}$ and $0.64 \mathrm{~g} \mathrm{~m}^{-3}$ respectively (Ratkova et al. 1989). In autumn, these sharp maxima have not been observed and Nitzschia spp. is more evenly distributed throughout the euphotic zone.

The winter bloom period of the annual life cycle of Nitzschia spp has not been well studied. This study provides results of winter observations on spatial distribution, division rates and photoadaptation in $N$. delicatula in open waters of the Black Sea.

\section{MATERIAL AND METHODS}

Collection of samples. A winter cruise by the RV 'Vityaz' was conducted in 1991 in 2 parts: 11 February to 5 March, and 10 March to 3 April. The 26 stations visited were located mainly in open areas of the Black Sea (Fig. 1). Special attention was paid to the eastern cyclonic gyre 7 vertical series of samples were taken at its center (Stns 3311-3311e). In addition 2 diurnal time-series observations on surface phytoplankton were carried out in the gyre in February and March. Phytoplankton studies were performed together with CTD (Jakubenko \& Esaulov 1992), PAR (Nikolaev \& Sasin 1992) and nutrient concentration measurements (data from Yu. Nalbandov).

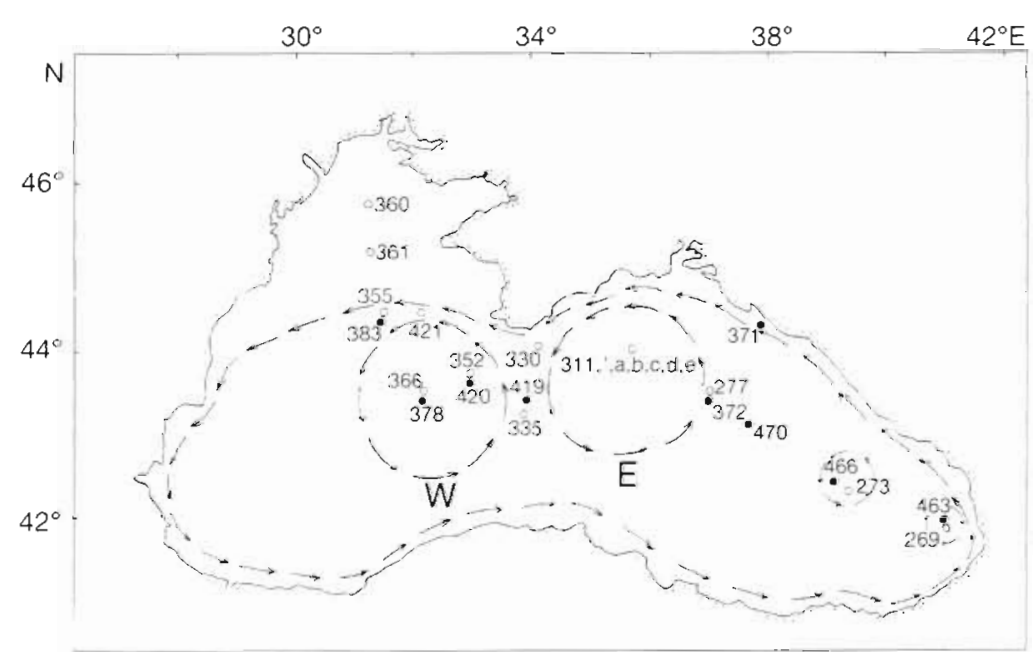

Fig. 1. Black Sea. Main currents (from Ovchinnikov \& Popov 1990 ) and sampling sites. (0) First cruise stations (February-March); (•) second cruise statıons (March-Aprl). E. W: eastern and western cyclonic gyres
Table 1. Sampling dates and some physical and biological characters of the stations. Temp.. surface temperature; Sec.: Secchi disk transparency; $D_{z}$ : mixed layer depth; biomass: total phytoplankton wet biomass. "Water column without a density gradient; nd: no data

\begin{tabular}{|ccccccc|}
\hline Stn & $\begin{array}{c}\text { Date } \\
(1991)\end{array}$ & $\begin{array}{c}\text { Temp. } \\
\left({ }^{\circ} \mathrm{C}\right)\end{array}$ & $\begin{array}{c}\text { Sec. } \\
(\mathrm{m})\end{array}$ & $\begin{array}{c}D_{z} \\
(\mathrm{~m})\end{array}$ & $\begin{array}{c}\text { Sampling } \\
\text { depth }(\mathrm{m})\end{array}$ & $\begin{array}{c}\text { Biomass } \\
\left(\mathrm{g} \mathrm{m}^{-2}\right)\end{array}$ \\
\hline 3269 & $11 \mathrm{Feb}$ & 6.3 & 9 & 115 & 130 & 10.3 \\
3273 & $12 \mathrm{Feb}$ & 8.4 & 8 & nd & 100 & 9.5 \\
3277 & $13 \mathrm{Feb}$ & 6.6 & 8 & 45 & 100 & 20.0 \\
3311 & $18 \mathrm{Feb}$ & 5.8 & 8 & 32 & 100 & 67.0 \\
3311 & $20 \mathrm{Feb}$ & 5.8 & 7 & 28 & 35 & $\mathrm{nd}$ \\
$3311 \mathrm{a}$ & $22 \mathrm{Feb}$ & 5.5 & 6.5 & 32 & 85 & 72.8 \\
$3311 \mathrm{~b}$ & $05 \mathrm{Mar}$ & 5.7 & nd & 35 & 80 & 78.1 \\
$3311 \mathrm{c}$ & $12 \mathrm{Mar}$ & 6.1 & $\mathrm{nd}$ & 22 & 75 & 33.8 \\
$3311 \mathrm{~d}$ & $25 \mathrm{Mar}$ & 6.2 & 6.5 & 23 & 70 & 62.2 \\
$3311 \mathrm{e}$ & $03 \mathrm{Apr}$ & 6.2 & nd & 23 & 70 & 40.9 \\
3330 & $24 \mathrm{Feb}$ & 6.8 & 8 & 58 & 100 & 126.1 \\
3335 & $27 \mathrm{Feb}$ & 6.5 & 7 & 54 & 100 & 64.3 \\
3352 & $01 \mathrm{Mar}$ & 6.6 & 8 & 30 & 80 & 59.1 \\
3355 & $02 \mathrm{Mar}$ & 6.7 & 8.5 & 44 & 100 & 43.5 \\
3360 & $03 \mathrm{Mar}$ & 4.6 & 7.5 &. & 28 & 64.3 \\
3361 & $04 \mathrm{Mar}$ & 6.0 & 6 &. & 44 & 3.9 \\
3366 & $04 \mathrm{Mar}$ & 6.7 & 7.5 & 44 & 100 & 61.5 \\
3371 & $10 \mathrm{Mar}$ & 8.4 & 9 & 88 & 100 & 13.0 \\
3372 & $11 \mathrm{Mar}$ & 6.1 & 7 & 34 & 100 & 57.0 \\
3378 & $13 \mathrm{Mar}$ & 6.3 & 8 & 40 & 100 & 78.0 \\
3383 & $14 \mathrm{Mar}$ & 6.8 & 10 & 102 & 105 & 21.4 \\
3419 & $18 \mathrm{Mar}$ & 6.9 & 7 & 60 & 100 & 41.1 \\
3420 & $19 \mathrm{Mar}$ & 6.5 & 6 & 44 & 100 & 82.1 \\
3463 & $30 \mathrm{Mar}$ & 9.2 & 9 & 116 & 120 & 8.3 \\
3466 & $01 \mathrm{Apr}$ & 8.8 & 10 & 52 & 100 & 30.3 \\
3470 & $02 \mathrm{Apr}$ & 7.9 & 9 & 43 & 70 & 36.3 \\
& & & & & & \\
\hline
\end{tabular}

Samples were collected with a $150 \mathrm{l}$ plastic sampler (Institute of Oceanology construction). The vertical sampling series began as a rule at 09:00 $\mathrm{h}$ and consisted of 7 or 8 samples down to depths of 75 to $130 \mathrm{~m}$ (Table 1). Samples collected during the diurnal observations were taken with a bucket or a rosette mounted with 4 l samplers.

Microscopic observations. A combination of 2 methods was used to estimate the size and taxonomic composition of phytoplankton. Cells of microphytoplankton (over $15 \mu \mathrm{m}$ in length) from 1 to 5 l samples were concentrated over a $1.0 \mu \mathrm{m}$ Nuclepore filter. Cells were examined and enumerated under light microscopes in nonfixed concentrates (from 30 to $40 \mathrm{ml}$ ) on the day of collection (data of Drs L. V. Georgieva and D. A. Nesterova). Under bloom conditions, cells of Nitzschia spp. were counted in unconcentrated natural water samples. At 20 stations, the number of dividing cells of $N$. delicatula was also 
counted. Dividing cells were determined as cells at a certain stage (terminal event) of the cell division cycle. Terminal event was defined as the period between a cell with double chloroplasts and a pair of young cells remaining together. This pair of young cells was considered as a single dividing cell if the cells were shifted along each other not more than $1 / 3$ of the cells' length. Some samples were fixed with formalin and examined later for detailed taxonomic identification using electron microscopy by Dr G. I. Semina.

Small phytoplankton (under $15 \mu \mathrm{m}$ ) were enumerated using epifluorescent microscopy (data from E. N. Kokurkina). Aliquots (25 to $50 \mathrm{ml}$ ) of the collected samples were fixed with glutaraldehyde (up to $1 \%$ of final concentration). After $20 \mathrm{~min}$, the aliquots were filtered through $0.2 \mu \mathrm{m}$ Nuclepore filters which had been previously stained with Sudan Black, in order to prevent autofluorescence of the filter. Following filtering, algae cells were stained with primulin (Caron 1983). Slides with the filters were examined microscopically [LUMAM-13, Leningrad's Optic Mechanical Company (LOMO), Russia) using blue excitation. Eukaryotes fluoresced red and cyanobacterial cells yellow-orange. Cells were counted by transects or fields of vision and a part of the total filter area was investigated. In the case of nanophytoplankton (from 2 to $15 \mu \mathrm{m}$ ), this part corresponded to $0.1-1 \mathrm{ml}$ of the filtered water In the case of picophytoplankton (under $2 \mu \mathrm{m}$ ) this value varied from 0.001 to $1.0 \mathrm{ml}$.

Cell volumes were calculated from the cell's measured dimensions using geometrical formulae. Wet biomass was assumed to be equal to cell volume. For microphytoplankton, cell carbon was estimated using conversions from cell volume (Strathmann 1967). Because the equations overestimated the carbon cell content in a small alga (Booth 1988), the carbon percent of cell volume was assumed to be $15 \%$ for nanophytoplankton and $20 \%$ for picophytoplankton (Kana \& Glibert 1987).

Measurement of single cell fluorescence. Fluorescent signals were recorded from single cells of Nitzschia delicatula. A fluorimeter (FMEL, LOMO) combined with a fluorescent microscope (LUMAM-R8, LOMO) was used. A mercury vapour lamp ( $250 \mathrm{~W}$ ) was used as a light source. Filters were combined as follows: blue exciting ( 400 to $460 \mathrm{~nm}$ ), yellow-green barrier and red (maximum penetration at $680 \mathrm{~nm}$ wavelength) emission filters. Fluorescence of the standard was recorded before and after the measurements in each sample to check the stability of the equipment.

Fluorescence was measured on slides similar to those used for small phytoplankton counts. Prior to measurements, slides were kept at $-15^{\circ} \mathrm{C}$. Cells were initially located within the field of vision of the microscope, using a weak excitation which did not cause the chloroplast's destruction. Then the cell was superim- posed on the fluorimeter window, the full exciting light was turned on and the maximum reading of the voltmeter was recorded. At least 20 cells were examined for each sample. Because there are no data on converting fluorescence intensity to chlorophyll (chl) concentration for Nitzschia delicatula cells, the measured fluorescence was only used as an index of the relative changes in cellular chl content.

Growth-rate and light-adaptation experiments. For growth-rate experiments, subsamples from the upper $10 \mathrm{~m}$ were drawn into 2 light bottles $(250 \mathrm{ml})$. Incubation was carried out on the deck in a plastic tank with continuous water flow at temperatures close to in situ conditions $\left(6\right.$ to $\left.8^{\circ} \mathrm{C}\right)$. Bottles were wrapped in several layers of white nylon mesh. The percent of light penetration into the bottles was determined using a spectrophotometer (SF-18, LOMO). In the growth-rate experiments, illumination conditions corresponded to ca $50 \%$ of surface radiation. Exposures were started at midday and the duration ( $t$ ) varied from 24 to $48 \mathrm{~h}$. Based on the initial $\left(N_{0}\right)$ and final $\left(N_{t}\right)$ cell numbers, the following growth parameters were calculated:

specific growth rate $\quad \mu=(1 / t) \ln \left(N_{i} / N_{0}\right)$ population doubling time $D T=(\ln 2) / \mu$

terminal event duration $T=t \ln (M+1) / \ln \left(N_{t} / N_{0}\right)$

where $M$ is the mitotic index (Weiler \& Chisholm 1976), defined as the share of dividing cells in the total number of cells. Using the mean $T$ value measured in the experiments and field data on carbon biomass $(B)$ and on $M$, the production $(P)$ of Nitzschia delicatula population was estimated as:

where

$$
\mathrm{P}=B\left(\mathrm{e}^{\mu t}-1\right)
$$

according to McDuff \& Chisholm (1982).

Experiments on the light adaptation response of Nitzschia delicatula were conducted under the same conditions as the growth-rate experiments. Samples were taken from 3 different depths within the euphotic zone and exposed to uniform light conditions. Slides for cell chl measurements were prepared initially at 12:00 $\mathrm{h}$ and then after $2,6,12$ and $24 \mathrm{~h}$ of incubation. Changes in cellular chl observed in experiments were considered to be the cell light-adaptation response.

Random errors of cell abundance were calculated based on total cell numbers using a normal approximation (Venrick 1978). For Mvalues, $95 \%$ confidence limits were obtained using a Poisson distribution based on the number of dividing cells (Weiler \& Chisholm 1976). Standard deviations of mean cellular chl were estimated from fluorescence signal measurements in each sample using standard formulae. The significance of the difference between the initial and the final values in experiments was determined by Student's $t$-test. 


\section{RESULTS}

\section{Spatial distribution}

Species identifications conducted with electron microscopy revealed that the phytoplankton was dominated by Nitzschia delicatula. Cell lengths ranged from 60 to $110 \mu \mathrm{m}$, with maximum cell diameter of 1.5 to $3.5 \mu \mathrm{m}$ and cell volume of 120 to $830 \mu \mathrm{m}$ (mean $440 \mu^{3}$ ). Concomitant species were $N$. closterium, $N$. seriata, Thalassionema nitzschioides, and Cerataulina bergonii. Microphytoplankton contributed the main portion of the total phytoplankton wet biomass (from 46 to $97 \%$, mean $87 \%$ ). Nanophytoplankton comprised 2 to $53 \%$ (mean $12 \%$ ) and picophytoplankton 0.02 to $15 \%$ (mean $2 \%$ ) of the phytoplankton standing stock.

Total phytoplankton biomass ranged from 8.3 to $126 \mathrm{~g} \mathrm{~m}^{-2}$ (Table 1). Spatial changes in biomass were determined by the distribution of Nitzschia delicatula which constituted 39 to $87 \%$ (mean $72 \%$ ) of the phytoplankton standing stock (Table 2). Cell numbers in the upper mixed layer varied from $8 \times 10^{6}$ to $6 \times 10^{9}$ cells $\mathrm{m}^{-3}$. Wet biomass was as high as $2.7 \mathrm{~g} \mathrm{~m}^{-3}$. High values of carbon biomass ( 3 to $5 \mathrm{~g} \mathrm{C} \mathrm{m}^{-2}$ ) were observed



Fig. 2. Nitzschia delicatula. Distribution of carbon (open columns), production (filled columns) and daily $P / B$ coefficients (•). (A) Transect in February-March; (B) transect in March-April; (C) at center of eastern cyclonic gyre (Stn 3311 series)
Table 2. Nitzschia delicatula. Abundance $\left(N, 10^{3}\right.$ cells $\left.1^{-1}\right)$, share in total phytoplankton biomass $(\%)$, mitotic index $(M)$, $P / B$ coefficients $\left(\mathrm{d}^{-1}\right.$, average for the upper mixed layer) and $H$ coefficients. nd: no data. See text for explanation of $M$ and $H$

\begin{tabular}{|lrrrrr|}
\hline Stn & $N$ & $\%$ & $M$ & $P / B$ & $H$ \\
\hline 3277 & 390 & 39 & 0.04 & 0.25 & 0.6 \\
3311 & 3970 & 87 & 0.02 & 0.07 & 0.4 \\
$3311^{\circ}$ & 2950 & nd & 0.04 & 0.17 & 0.8 \\
$3311 \mathrm{a}$ & 3910 & 83 & 0.05 & 0.17 & 0.7 \\
$3311 \mathrm{~b}$ & 3400 & 78 & 0.11 & 0.41 & 0.9 \\
$3311 \mathrm{c}$ & 1510 & 77 & 0.21 & 0.83 & 1.0 \\
$3311 \mathrm{~d}$ & 4190 & 81 & 0.04 & 0.16 & 0.7 \\
$3311 \mathrm{e}$ & 2234 & 62 & 0.04 & 0.13 & 0.5 \\
3330 & 3784 & 84 & 0.04 & 0.13 & 0.5 \\
3335 & 1930 & 82 & 0.03 & 0.09 & 0.2 \\
3352 & 3000 & 83 & 0.17 & 0.72 & 0.9 \\
3355 & 1430 & 74 & 0.11 & 0.50 & 0.4 \\
3366 & 1286 & 74 & 0.05 & 0.21 & 0.6 \\
3372 & 2466 & 74 & 0.08 & 0.37 & 0.5 \\
3378 & 3000 & 77 & 0.15 & 0.64 & 0.5 \\
3383 & 50 & 46 & 0.11 & 0.52 & $\mathrm{nd}$ \\
3419 & 1100 & 65 & 0.04 & 0.17 & 0.5 \\
3420 & 2920 & 82 & 0.09 & 0.37 & 0.4 \\
3466 & 100 & 56 & 0.01 & 0.05 & 0.2 \\
3470 & 1200 & 67 & 0.01 & 0.04 & 0.4 \\
\hline
\end{tabular}

in the central parts of the eastern and western gyres (Fig. 2). During the first part of the cruise the highest biomass (up to $8.6 \mathrm{~g} \mathrm{~m}^{-2}$ ) was recorded at the convergence (Stns 3330 and 3335) between the 2 gyres (Fig. 2A). During the March-April observations, Stn 3330 was not repeated. However, at Stn 3419 (previously 3335 ) the biomass was less than at the centers of the gyres (Fig. 2B). The abundance of $N$. delicatula at the center of the eastern gyre varied from 1 to $4.6 \mathrm{~g} \mathrm{C} \mathrm{m}^{-2}$ (Fig. 2C). High values were observed both in February (Stn 3311a, b) and in March (Stn 3311d).

The biomass of Nitzschia delicatula in the central parts of both cyclonic gyres was more or less uniform in the upper mixed layer (Figs. $3 \& 4$ ). Below the pycnocline, cell abundance sharply decreased. Away from the centers of the gyres, biomass was distributed more heterogeneously. As a rule, vertical profiles showed a surface peak and/or a deep maximum located above the pycnocline. During the first part of the cruise, deep peaks were observed in the central Black Sea (Fig. 3), while in March-April maxima were recorded to the west of the western gyre and to the east of the eastern gyre (Fig. 4).

\section{Cell division}

The proportion of dividing cells in the population of Nitzschia delicatula varied over a wide range (from 0 
to 0.37 ) (Table 2). High $M$ indices (from 0.05 to 0.21 , on average, for the upper mixed layer) were observed in the central area of the sea. Maxima of $M$ were recorded near the surface as well as within the upper mixed layer. Below the pycnocline, $M$ was low and the seldom-dividing cells were observed down to a depth of $70 \mathrm{~m}$.

Diurnal observations indicated that there were substantial oscillations in both cell numbers and $M$ (Fig. 5). $M$ varied from 0.015 to 0.075 during the first series. Maxima were recorded at $16: 00$ and $06: 00 \mathrm{~h}$ (Fig. 5A). During the second series, $M$ varied from 0.04 to 0.15 . Peaks occurred at 09:00, 18:00 and 06:00 $\mathrm{h}$ (Fig. 5B). In 2 observations, similarity in time of peaks occurring was absent. In both cases, increases in Nitzschia delicatula abundance following peaks in $M$ were not observed.

\section{Population growth rate}

A significant difference between the initial and the final cell concentrations was observed in 8 out of 40 growth-rate experiments (Table 3). Specific growth rates and population doubling times differed by a factor of 3. Maximum growth rates were observed in Expts 7 and 8, coinciding with the minimum cell abundance. Duration of the terminal event varied from 4 to $9.6 \mathrm{~h}$ with an average of $7.2 \mathrm{~h}$.

High estimated rates of $P$ (from 1 to $3 \mathrm{~g} \mathrm{C}$ $\mathrm{m}^{-2} \mathrm{~d}^{-1}$ ) were recorded in both gyres (Fig. 2A, B). High daily $P / B$ coefficients $(0.5$ to 0.8$)$ were also obtained in the central parts of the gyres (Fig. 2A, B). In the peripheral regions, growth rates of Nitzschia delicatula decreased and $P / B$ varied from 0.05 to 0.2 . Over the $1.5 \mathrm{mo}$ period at the center of the eastern gyre, $P$ varied from 0.5 to $1.8 \mathrm{~g} \mathrm{C} \mathrm{m}^{-2} \mathrm{~d}^{-1}$ (Fig. 2C). Active growth of $N$. delicatula was observed in early March (Stn 3311b,c). The maximum $P / B$ coefficient was recorded to coincide with the lowest cell abundance. At the beginning of April (Stn 3311 e) simultaneous with the formation of the seasonal thermocline, biomass and $P / B$ decreased to a low level.

Phytoplankton abundance was related to the mixed layer depth $\left(D_{z}\right)$ and with the Sverdrup's (1953) ratio between $D_{z}$ and the compensation point depth $\left(D_{c}\right)$, assumed here to be at the depth of $1 \%$ of the surface irradiance. Strong negative exponential correlation

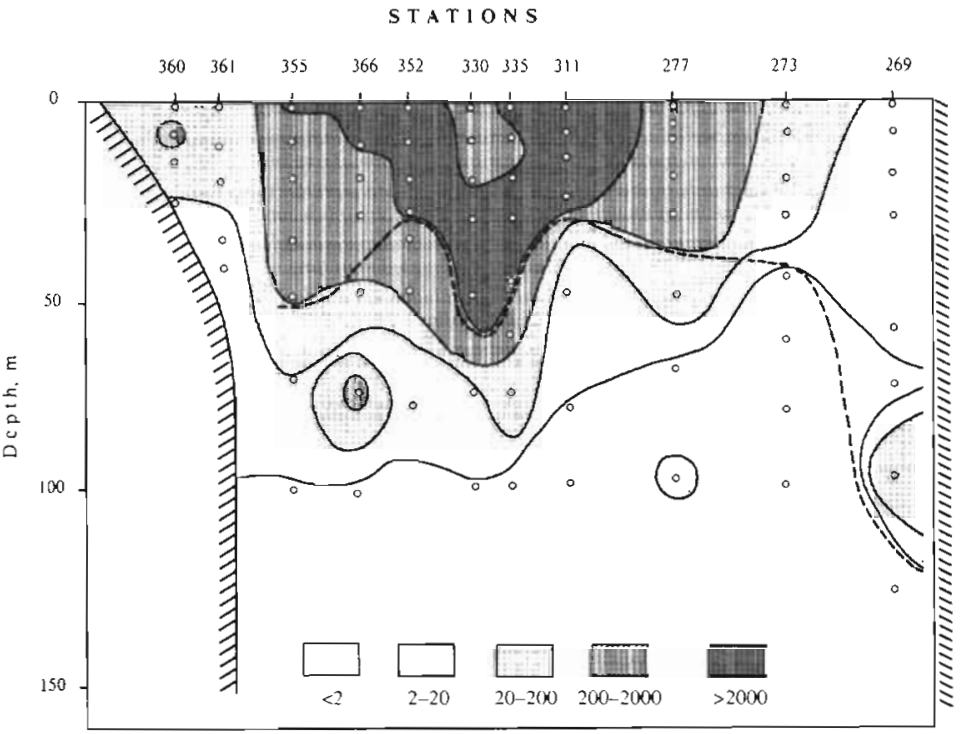

Fig. 3. Nitzschia delicatula. Vertical distribution $\left\{\right.$ cells $\left.\times 10^{3} 1^{-1}\right\}$ on a transect in February-March. Points denote sampling depths; dotted line denotes the pycnocline

$S T+$ T IONS

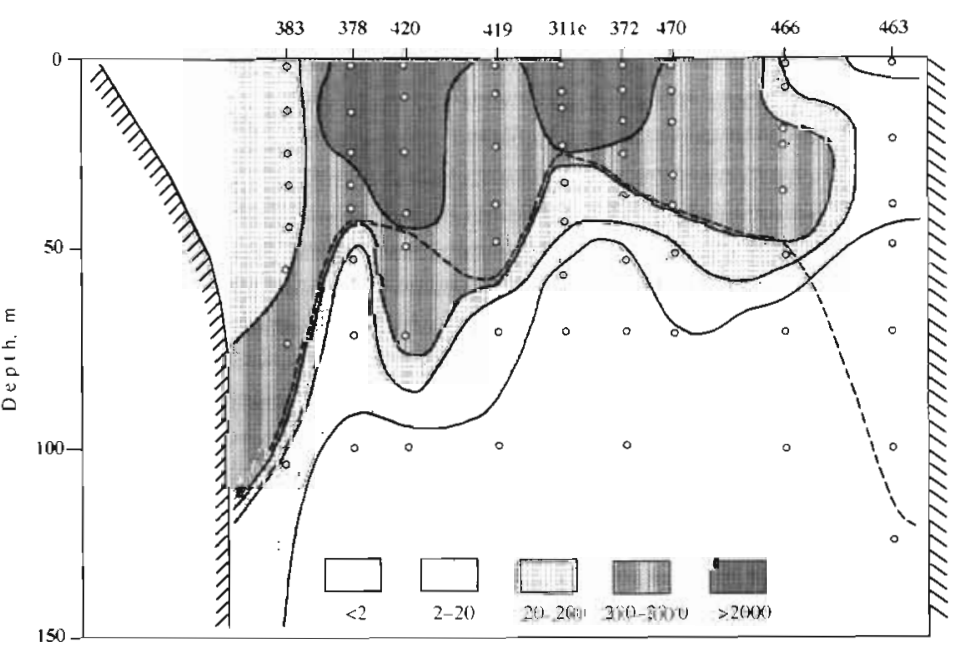

Fig. 4. Nitzschia delicatula. Vertical distribution (cells $\times 10^{3} \mathrm{l}^{-1}$ ) on a transect across the sea during March-April. Points denote sampling depths; dotted line denotes the pycnocline

was observed between the biomass of Nitzschia delicatula and $D_{\mathrm{z}}$ ( $\left.\mathrm{n}=23, \mathrm{r}=-0.86, \mathrm{p}<0.01\right)$ and between the biomass and $D_{z} / D_{c}$ ratio $(n=19, r=-0.87, p<0.02)$. In contrast, growth rate did not vary with these parameters nor with the cell abundance nor with the concentration of major nutrients such as $\mathrm{PO}_{4}, \mathrm{NO}_{2}+\mathrm{NO}_{3}$ and $\mathrm{Si}$. No relationship between the $P / B$ coefficients and wind forcing occurring 1 to $3 \mathrm{~d}$ before the observations was found. 


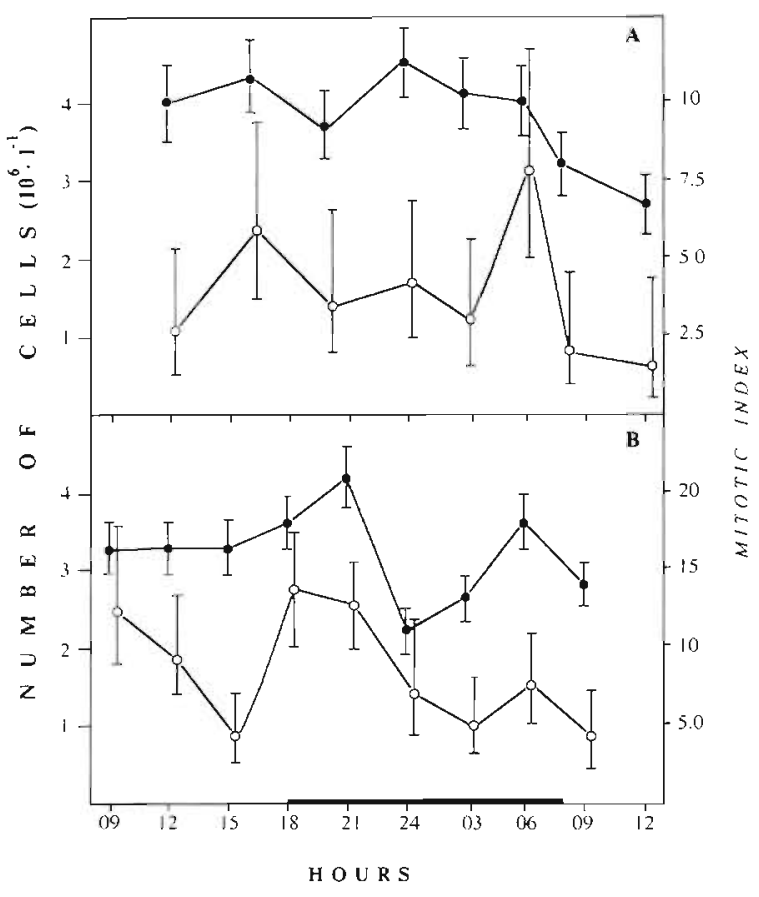

Fig. 5. Nitzschia delicatula. Cell numbers (•) and mitotic index $(M, \%, 0)$ during 2 diurnal series. Error bars indicate $95 \%$ confidence limits. Black horizontal bar indciates time of darkness

\section{Cellular chl distribution}

The vertical profiles of cellular chl (fluorescence cell intensity) of Nitzschia delicatula were similar at almost all stations. The cell chl content was at a minimum near the surface and gradually elevated with depth in the upper layer (Fig. 6). Steep increases were observed in the pycnocline or immediately below it. At greater depths, the distribution of cellular chl in the population was very heterogeneous. Cells with both very high chl content as well as with very low chl content (appar-

Table 3. Nitzschia delicatula. Growth parameters of cells. $N_{0}$ and $N_{1}$ : initial and final cell concentration (cells $10^{3} \mathrm{l}^{-1} \pm \mathrm{SD}$ ); $t$ : duration of experiment (h); $M$ : mitotic index (mean of initial and final values); $\mu$ : specific growth rate

$\left(\mathrm{d}^{-1}\right) ; D T \cdot$ population doubling time $(\mathrm{d}) ; T$ duration of terminal event $(\mathrm{h})$

\begin{tabular}{|cccccccc|}
\hline Expt & $N_{0}$ & $N_{t}$ & $t$ & $M$ & $\mu$ & $D T$ & $T$ \\
\hline 1 & $2683 \pm 134$ & $3277 \pm 148$ & 24 & 0.07 & 0.20 & 3.4 & 8.1 \\
2 & $2992 \pm 148$ & $4645 \pm 148$ & 48 & 0.06 & 0.22 & 3.2 & 6.4 \\
3 & $1571 \pm 68$ & $1843 \pm 74$ & 24 & 0.03 & 0.16 & 4.2 & 4.4 \\
4 & $1321 \pm 54$ & $1565 \pm 58$ & 24 & 0.07 & 0.17 & 4.0 & 9.6 \\
5 & $1457 \pm 75$ & $2402 \pm 96$ & 48 & 0.07 & 0.25 & 2.8 & 6.5 \\
6 & $2393 \pm 118$ & $2982 \pm 132$ & 24 & 0.09 & 0.22 & 3.2 & 9.4 \\
7 & $333 \pm 21$ & $785 \pm 31$ & 42 & 0.20 & 0.49 & 1.4 & 8.9 \\
8 & $783 \pm 46$ & $1111 \pm 154$ & 24 & 0.06 & 0.35 & 2.0 & 4.0 \\
$\bar{x}$ & & & & & 0.26 & 3.0 & 7.2 \\
\hline
\end{tabular}
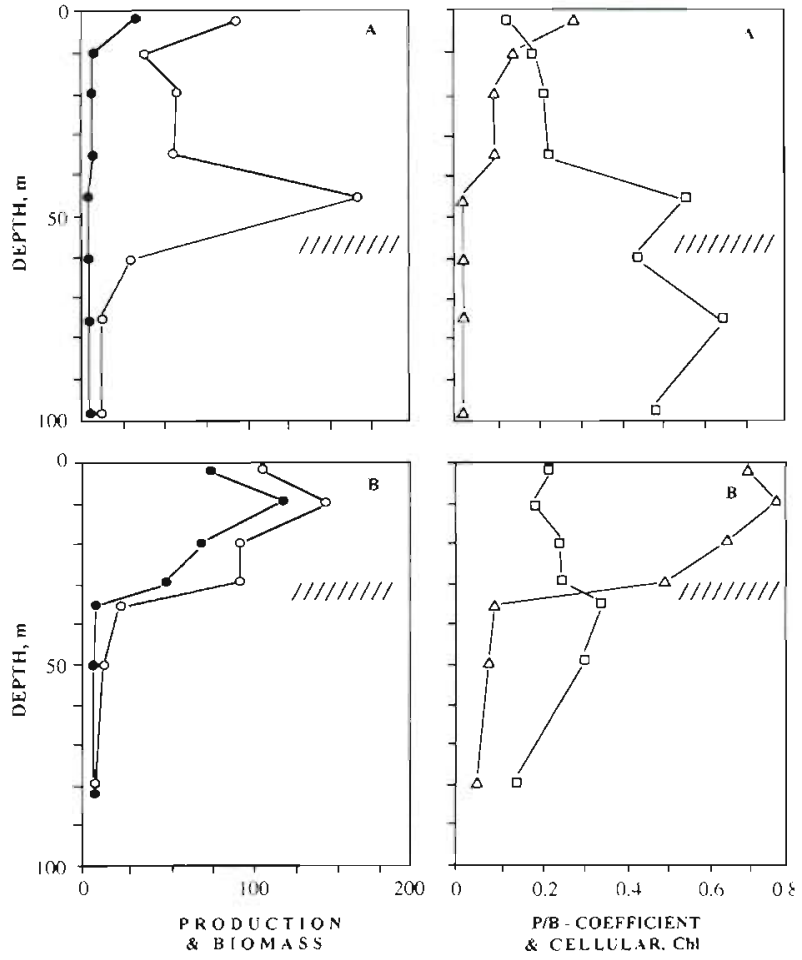

Fig. 6. Nitzschia delicatula. Vertical distribution carbon (mg C $\left.\mathrm{m}^{-3}, \bullet\right)$, production ( $\mathrm{mgC} \mathrm{m}^{-3} \mathrm{~d}^{-1}, O$ ), daily $P / B$ coefficients $(\Delta)$ and cellular chlorophyll (relative units, $D$ ) at (A) Stn 3335 and $(B) \operatorname{Sin} 3352$. Hatched area indicates the pycnocline

ently senescent cells) were observed. As a result, the mean cellular chl in the population was less than that in layers above.

Cell chl content reflects the 'light history' of algae, i.e. the mean irradiance received by the phytoplankton cell. It should be expected that, with active mixing processes, cellular chl will be uniform and under opposite conditions, with strong water column stratification, it will be heterogeneous (Lewis et al. 1984). Hence, homogeneity or heterogeneity in the vertical distribution of cellular chl content can indicate the previous activity of mixing. In this study, a coefficient of 'homogeneity' $(H)$ was applied. It was defined as the ratio between the cell chl content at the surface and the cellular chl at the bottom of the upper mixed layer. $H$ is close to zero with a heterogeneous vertical distribution and close to 1 with a uniform distribution. In the present study it ranged from 0.5 to 1.0 (mean 0.8 ) at stations with a shallow pycnocline position (less than $35 \mathrm{~m}$ ) and from 0.2 to 0.6 (mean 0.4 ) where the pycnocline was deeper. A positive linear correlation between $H$ and $P / B$ 


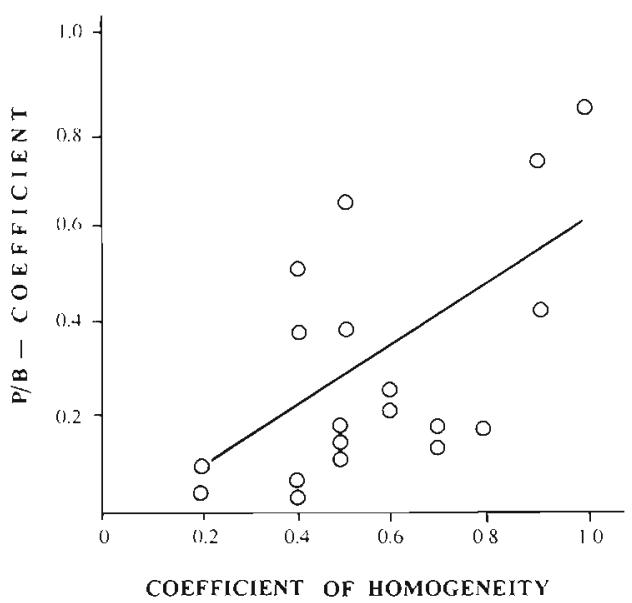

Fig. 7 Nitzschia delicatula. Relationship between $P / B$ coefficients and $H$ coefficients (homogeneity)

coefficients (Fig. 7) was obtained ( $\mathrm{n}=20, \mathrm{r}=0.6, \mathrm{p}<$ 0.01).

Vertical changes in cell chl content were related to the distribution of phytoplankton biomass and growth rates. Where a more heterogeneous distribution of cellular chl was observed, there were 2 peaks in phytoplankton carbon: surface and deep (Fig. 6A; $H=0.2$ ). $P$ and $P / B$ profiles had pronounced maxima near the surface indicating that cells at depth were not actively growing. Where a uniform distribution of cellular chl was observed, both $P$ and $P / B$ coefficients had high values throughout the entire upper mixed layer (Fig. 6B; $H=0.9$ ).

Table 4. Nitzschia delicatula. Photoadaptational response in 4 experimental series. $I$ and $I_{\mathrm{e}}$ : irradiance at sampling depth and in experiment ( $\%$ of surface irradiance); $F_{0}$ and $F_{1}$ : initial and final cell fluorescence (relative units $\pm \mathrm{SD}$ ); $A$ : presence $(+)$ or absence (-) of adaptation; $t$ : period of observed adaptation $(h)$

\begin{tabular}{|c|c|c|c|c|c|c|c|}
\hline Series & $\begin{array}{c}\text { Depth } \\
\text { (m) }\end{array}$ & $I$ & $I_{\mathrm{e}}$ & $F_{0}$ & $F_{i}$ & $A$ & $t$ \\
\hline 1 & $\begin{array}{r}2 \\
10 \\
25\end{array}$ & $\begin{array}{r}60 \\
15 \\
1\end{array}$ & $\begin{array}{l}100 \\
100 \\
100\end{array}$ & $\begin{array}{l}144 \pm 45 \\
155 \pm 53 \\
182 \pm 66\end{array}$ & $\begin{array}{l}94 \pm 39 \\
93 \pm 30 \\
74 \pm 35\end{array}$ & $\begin{array}{l}+ \\
+ \\
+\end{array}$ & $\begin{array}{r}8 \\
8 \\
24\end{array}$ \\
\hline 2 & $\begin{array}{l}10 \\
30 \\
50\end{array}$ & $\begin{array}{l}20 \\
1 \\
0.05\end{array}$ & $\begin{array}{l}10 \\
10 \\
10\end{array}$ & $\begin{array}{c}89 \pm 44 \\
125 \pm 74 \\
255 \pm 110\end{array}$ & $\begin{array}{l}116 \pm 49 \\
107 \pm 54 \\
117 \pm 85\end{array}$ & $\begin{array}{l}- \\
- \\
+\end{array}$ & $\begin{array}{l}- \\
- \\
12\end{array}$ \\
\hline 3 & $\begin{array}{l}10 \\
40 \\
50\end{array}$ & $\begin{array}{l}10 \\
0.2 \\
0.05\end{array}$ & $\begin{array}{l}1 \\
1 \\
1\end{array}$ & $\begin{aligned} 79 & \pm 19 \\
146 & \pm 39 \\
204 & \pm 102\end{aligned}$ & $\begin{array}{r}78 \pm 29 \\
142 \pm 34 \\
118 \pm 43\end{array}$ & $\begin{array}{l}- \\
- \\
+\end{array}$ & $\begin{array}{l}- \\
- \\
12\end{array}$ \\
\hline 4 & $\begin{array}{r}2 \\
23 \\
35\end{array}$ & $\begin{array}{l}60 \\
1.0 \\
0.1\end{array}$ & $\begin{array}{l}1 \\
1 \\
1\end{array}$ & $\begin{array}{r}92 \pm 27 \\
173 \pm 60 \\
177 \pm 58\end{array}$ & $\begin{aligned} 83 & \pm 26 \\
188 & \pm 60 \\
193 & \pm 100\end{aligned}$ & $\begin{array}{l}- \\
- \\
-\end{array}$ & $\begin{array}{l}- \\
- \\
-\end{array}$ \\
\hline
\end{tabular}

In 3 of 4 experimental series, the photoadaptational responses in Nitzschia delicatula cells were observed (Table 4). In the first experimental series, in all samples high surface irradiance caused the decrease in cell chl content after 8 to 24 h of exposure. In 3 other series, exposure under increased irradiance led to low cellular $\mathrm{chl}$ in 2 instances (samples from $50 \mathrm{~m}$ in Series 2 and 3). On these 2 occasions there was a 1.5 - to 2.5-fold difference between irradiance levels in bottles and in nature. Lower differences in irradiance level between native and experimental conditions (0.5- to 1 -fold) did not influence cell chl content (samples from 30,40 and $35 \mathrm{~m}$ in Series 2, 3 and 4). Exposure at reduced irradiance levels also did not affect the cell chl content

\section{DISCUSSION}

Earlier papers concerning the winter phytoplankton bloom in open waters of the Black Sea have indicated substantial diversity in the dominant species. In previous years, the phytoplankton mainly consisted of Coccolithus huxleyi (Belogorskaya \& Kondratieva 1965), Rhizosolenia spp. (Mashtakova \& Roukhiyainen 1979), Nitzschia delicatissima, $N$. seriata, and $R$. calcar-avis (Sukhanova et al. 1991a). In these lists $N$. delicatula was not mentioned. Nevertheless, its presence in deep accumulations in May 1986 suggests that a previous bloom of this alga occurred during winter (Ratkova et al. 1989). $N$ delicatula clearly dominated in phytoplankton in winter 1991 (Table 2). The maximum number of cells $\left(6.2 \times 10^{6}\right.$ cells $\left.1^{-1}\right)$ was higher than that of


et al. 1991a), while total biomass was similar and varied from 14 to $126 \mathrm{~g} \mathrm{~m}^{-2}$ in 1991 and from 10 to $100 \mathrm{~g}$ $\mathrm{m}^{-2}$ in 1988 . The winter bloom of both Nitzschia spp. had higher biomass than that of the winter phytoplankton dominated by any other alga. In 1956, phytoplankton biomass varied from 350 to $700 \mathrm{mg} \mathrm{m}^{-3}$ in the upper $50 \mathrm{~m}$ (Belogorskaya \& Kondratieva 1965). On average for the period from 1961 to 1976, biomass averaged $400 \mathrm{mg} \mathrm{m}^{-3}$ in the upper $25 \mathrm{~m}$ (Mashtakova \& Roukhiyainen 1979). Average values for the $50 \mathrm{~m}$ column were as high as $2000 \mathrm{mg} \mathrm{m}^{-3}$ in 1988 and $2200 \mathrm{mg} \mathrm{m}^{-3}$ in 1991.

The spatial distribution of the Nitzschia delicatula population (Figs. 2-4) in the open part of the Black Sea is in good agreement with the hydrological scheme of currents. The deep sub-pycnocline waters are elevated at the centers of the cyclonic gyres and then spread with a complex trajectory over the pycnocline to peripheral areas (Ovchinnikov \& Popov 1990). This process governs the presence of water 'tongues' above the pycnocline containing phytoplankton that developed in the centers of the gyres. Such layers have been 
observed in the central Black Sea during the first set of observations (see Fig. 3) and in peripheral areas during March-April 1991 (see Fig. 4). These populations originated from the centers of the gyres. It seems that population observed in the northwestern part (Fig. 2, Stns 3360 and 3361) and in deep waters near the eastern shelf (Fig. 3, Stn 3269) must have had a local origin.

The influence of mixing on production in diatom populations is well known (e.g. Steele 1959, Eppley et al. 1978. Marra 1978, Yentsch 1981, Lewis et al 1984, Jones \& Gowen 1990). In winter, the vertical circulation of waters in the Black Sea is strongly influenced by the wind regime, both in open-sea and coastal regions (Filipov 1968). The relationship between the weather in winter and phytoplankton biomass was observed in the eastern Black Sea (Mashtakova \& Roukhiyainen 1979). Total phytoplankton biomass averaged $36 \mathrm{mg} \mathrm{m}^{-3}$ for years with calm weather and $918 \mathrm{mg} \mathrm{m}^{-3}$ for winters with strong storm events. Such wind-induced enhancement of primary production is considered to be caused by replenishing of the photosynthetic layer with biogenic elements (Finenko 1978). The wind-mixed layer can spread down to the pycnocline depth or end above it (e.g. Fennel et al. 1986, Yamazaki \& Kamykowski 1991). In the first case, wind-induced mixing causes the erosion of the upper margin of the pycnocline (Klein \& Coste 1984, Ovchinnikov et al. 1991) and provides a mechanism for transport of nutrients into the upper mixed layer (Eppley \& Renger 1988). Such short-term enhancement of biogenic elements in the mixed layer after the storm events have been reported (Legendre 1981, Sambrotto et al. 1986). During our observations, mean daily wind velocity varied from 3 to $12 \mathrm{~m} \mathrm{~s}^{-1}$ with an average of $5.7 \mathrm{~m} \mathrm{~s}^{-1}$. At some stations in the central sea, these winds caused mixing throughout down to the shallow pycnocline position. This can be verified by profiles of cell chl content which indicated a homogeneity $(H=0.8$ to 1.0$)$ in the population of Nitzschia delicatula (Table 2, Fig. 6B). High phytoplankton biomass and growth rates with low ammonium content (0.1 to $0.5 \mu \mathrm{g}$-at. $\left.\mathrm{l}^{-1}\right)$ indicated high 'new' production (Dugdale \& Goering 1967) and, hence, indicated the penetration of nutrients into the upper mixed layer. Nevertheless, the mixed layer was not saturated with biogenic elements. Concentrations varied from 0.1 to $0.3 \mu \mathrm{g}$-at. $\mathrm{PO}_{4} 1^{-1}$, from 0.0 to $0.2 \mu \mathrm{g}$-at. $\mathrm{NO}_{2}+\mathrm{NO}_{3} 1^{-1}$ and from 0.2 to $3.2 \mu \mathrm{g}$-at. Si $1^{-1}$. Such low nutrient content and the absence of a correlation between these concentrations and wind forcing might have been due to intensive consumption of nutrients by the high phytoplankton biomass. Another explanation is that the short-term response to wind stress might have been missed in the wide time scale of our observations.
The shallow pycnocline creates generally favorable light conditions for phytoplankton development (Sverdrup 1953). Strong negative correlation between Nitzschia delicatula biomass and $D_{z}$ and $D_{z} / D_{c}$ ratios are in good agreement with this hypothesis. It seems that the shallow pycnocline is a necessary, but not sufficient, condition of phytoplankton bloom development. When the shallow pycnocline is present, active mixing may be the important factor directly affecting cell growth rates (Sambrotto et al. 1986). However, since mixing in the upper layer depends upon many factors including pycnocline depth, wind forcing, linear flow rates and internal waves (Denman \& Gargett 1983), each of these alone is not responsible for vertical cell displacements. Obviously for that reason $N$. delicatula growth rates were not related to $D_{z 1} D_{z} / D_{c}$ and wind forcing.

By contrast, the $H$ coefficient based on the cell's photoadaptational responses reflects the summary intensity of the cell's preceding vertical motion and functions as the ecological informative mixing index. The time period of previous mixing reflected by $H$ coefficients appears to be species-specific. In different species, the time scale of light adaptation revealed as changes in cell chl content varies from several hours to several days (Gallegos et al. 1983, Post et al. 1984). In short-term experiments with Nitzschia delicatula, decreases in cellular chl occurred under high-irradiation conditions (Table 4, Series 1). This might have been caused by chloroplast destruction. Decreases in cell chl content were also observed when the changes from low to high irradiance level greater than 1 -fold occurred (Table 4, Series $2 \& 3$ ). Inverse high to low irradiation changes did not led to cellular chl alterations (Table 4 , Series $3 \& 4$ ). These results of more rapid photoadaptational responses in 'low to high' than in 'high to low' irradiance changes are similar to the data reported for algae cultures (Post et al. 1984). Taking into account the 2-fold decrease in irradiance level within the upper mixed layer, it could be expected that water column stabilization must have caused a decline in chl content in $N$. delicatula cells near the surface over time scales of approximately $1 \mathrm{~d}$. This would mean that an $H$ coefficient equal to 1 indicated active mixing at least during the day before the observations. Such situation was only observed at Stn 3311c, which coincided with the maximal growth rate (0.83) recorded (Fig. 2C). High $H$ values occurred at the centers of the gyres and its relationship with the $P / B$ coefficients (Fig 7 ) indicate that when generally favorable light conditions are present, mixing in the upper layer increases cell growth rates in the $N$. delicatula population.

Primary production $(P P)$ in the central Black Sea measured in situ by the ${ }^{14} \mathrm{C}$ technique during the diatom bloom in March 1988 varied from 0.2 to $0.35 \mathrm{~g}$ 
C $\mathrm{m}^{-2} \mathrm{~d}^{-1}$ (Vedernikov 1991). Simultaneous determinations carried out in the western Black Sea in March 1988 (Krupatkina et al. 1991) revealed a higher value of $P P\left(0.58 \mathrm{~g} \mathrm{C} \mathrm{m}^{-2} \mathrm{~d}^{-1}\right.$ on average from 22 sampling sites). Similar PP values were recorded in phytoplankton communities dominated by Nitzschia delicatula during our expedition (Sorokin et al. 1992). PP varied from 0.2 to $0.96 \mathrm{~g} \mathrm{C} \mathrm{m}^{-2} \mathrm{~d}^{-1}$ (mean $0.46 \mathrm{~g} \mathrm{C} \mathrm{m}^{-2} \mathrm{~d}^{-1}$ ). $P$ estimated on the basis of cell division was substantially higher $\left(0.05\right.$ to $3.0 \mathrm{~g} \mathrm{C} \mathrm{m}^{-2} \mathrm{~d}^{-1}$, mean 1.08$)$ than $P P$ measured using ${ }^{14} \mathrm{C}$. In the central Black Sea, estimated $P$ was an average 2.3 times higher than $P P$ measured and at some sampling sites $P$ exceeded $P P$ by 4 to 6 times. Since the estimation was restricted to the $N$. delicatula population, the actual discrepancy between these 2 evaluations seems to be even larger.

The accuracy of $P$ estimations seems appropriate to evaluate. This primarily depends upon the precision of the $M$ measurements. While relative errors in each sample varied from 20 to $100 \%$, for mean values of $M$ in the upper mixed layer they did not exceed $30 \%$. The range of $M$ values obtained (0.04 to 0.37 ) is also consistent with data reported earlier for Nitzschia spp. The share of dividing cells in the $N$. delicatissima population during the bloom period in 1988 varied from 5 to $40 \%$ (Sukhanova et al. 1991b). In deep accumulations of $N$. delicatula during late spring, $M$ approached 0.5 (Ratkova et al. 1989).

The assumption about the absence of diurnal $M$ variation was applied to the $P$ estimations. In spite of the wide range of $M$ observed in the 2 diurnal series, repeated peaks followed by increases in cell abundance were not recorded (Fig. 4). Possibly a high patchiness in the spatial distribution of Nitzschia delicatula population occurred during sampling. Such heterogeneity in phytoplankton distributions is typical for highly productive waters (Strickland et al. 1969). In contrast to dinoflagellates, which usually have a pronounced time peak in mitotic activity (Swift \& Durbin 1972, Weiler \& Chisholm 1976, Stolbova et al. 1982, Chang \& Carpenter 1988, 1991), a low degree of synchrony in cell division is common for diatom species (Nelson \& Brand 1979, Olson \& Chisholm 1983, Mikaelyan 1984, Chang \& Carpenter 1991).

Eqs. (3) \& (5) are valid when $T$ is not highly variable with growth conditions, or if it is a function of $\mu$ (McDuff \& Chisholm 1982). The duration of the terminal event in experiments varied over a wide range (Table 3 ). Variation was highest among the short-term ( $24 \mathrm{~h}$ ) experiments. The coefficient of variation (CV) was 0.38 . This might have been due to a lag phase in cell adaptation to experimental conditions. Possibly for that reason, the long-term ( 42 to $48 \mathrm{~h}$ ) experiments provided more consistent results ( $\mathrm{n}=3, \mathrm{CV}=0.19)$. In spite of the substantial difference in variations the mean values in both short-term (24 h) and long-term (42 to $48 \mathrm{~h}$ ) experiments were very similar 7.1 and $7.3 \mathrm{~h}$ respectively. Similar $T$ values were observed in the Bering Sea in summer (unpubl. data). In 6 experiments conducted with the Nitzschia delicatula populations, $T$ varied from 6.3 to $8.0 \mathrm{~h}(\mathrm{n}=6, \mathrm{CV}=0.1)$ averaging $7.4 \mathrm{~h}$.

A weak positive dependence between $T$ and $M$ was found in our Black Sea experiments $(n=8, r=0.54, p<$ $0.2)$. This is in line with the data on dinoflagellate Gymnodinium cf. nagasakiense, in which duration of mitosis is proportional to the generation time (Videau $\&$ Partensky 1990). In diatom species $T$ is influenced by temperature (Olson et al. 1986). However, from this study any relationship found between the water temperature and the $T$ values was due perhaps to the narrow range of temperature values $\left(6.5\right.$ to $\left.10^{\circ} \mathrm{C}\right)$. Taking into account the similar $T$ values obtained in the Black and Bering Seas as well as the weak dependency of $T$ and $M$, it can be expected that the mean time of terminal event duration (7.2) used in calculations of $P$ is quite representative. It may be concluded that substantial systematic errors in $P$ estimations caused by the time of sampling or by incorrect determination of terminal-event duration did not occur. The random errors derived from $M$ determinations must have also been smoothed by averaging the high number of observations

The discrepancy between the 2 methods of $P$ evaluation might have resulted from the initial settings of in situ bottle measurements. Maximum growth rates and $P$ values of Nitzschia delicatula populations were observed in the central areas of the gyres (Fig. 2) and these coincided with high mixing activity in the upper layer (Fig. 7). In such situations static $P / I$ curves obtained from bottle techniques relating photosynthesis to the constant light levels may not be adequate to imitate the complex patterns of natural variation in light and nutrients (Yentsch 1981, Pahl-Wostl \& Imboden 1990). This suggestion is supported by the difference between these $P$ and $P P$ evaluations which was related to the $H$ coefficients. When the water column was stratified $(H<0.5)$, estimated $P$ was 1.5 times as high as that measured. In the well-mixed upper layer $(H>0.5)$ the ratio between these values was approximately 3 . Comparison of the photosynthesis and biosynthesis vertical profiles also corroborates this suggestion. At virtually all sampling locations, vertical curves of ${ }^{14} \mathrm{C}$ measured $P P$ had a pattern typical for highly productive waters: a pronounced maximum near the surface and exponential decrease with the depth (Sorokin et al. 1992). A similar distribution of estimated $P$ and growth rates was observed under stratified conditions (Fig. 6A), while the active mixing led to high growth rates throughout the upper layer (Fig. 6B), providing high $P$ values under the water column. 
Acknowledgements. I am grateful to Drs D. A. Nesterova, L. G. Georgieva and E. N. Kokurkina for data on cell counts and to Dr G. I. Semina for detailed taxonomic identifications. I thank Yu. Nalbandov for data on nutrient content and the various scientific groups of the cruise for assisting this study through provision of physical, optical and chemical measurements. I am also grateful to Academician M. E. Vinogradov for a critical reading of the manuscript and to Dr L. Cooper and to 3 anonymous referees for their valid comments and editing of the paper.

\section{LITERATURE CITED}

Belogorskaya EV, Kondratieva TM (1965) The distribution of the phytoplankton in the Black Sea. In: Studies of the plankton of the Black Sea and the Asov Sea. Naukova Dumka, Kiev, p 36-58 (in Russian)

Booth BC (1988) Size classes and major taxonomic groups of phytoplankton at two locations in the subarctic Pacific Ocean in May and August. 1984. Mar Biol 97(2):275-286

Caron D (1983) Technique for enumeration of heterotrophic and phototrophic nanoplankton using epifluorescence microscopy and comparison with other procedures. Appl environ Microbiol 46(2):491-498

Chang J, Carpenter EJ (1988) Species-specific phytoplankton growth rates via diel DNA synthesis cycles. II. DNA quantification and model verification in the dinoflagellate Heterocapsa triquetra. Mar Ecol Prog Ser 44:287-296

Chang J, Carpenter EJ (1991) Species-specific phytoplankton growth rates via diel DNA synthesis cycles. V. Application to natural populations in Long Island Sound. Mar Ecol Prog Ser 78:115-122

Dennman KL, Gargett A.E (1983) Time and space scales of vertical mixing and advection of phytoplankton in the upper ocean. Limnol Oceanogr 28(5):801-815

Dugdale RC, Goering JJ (1967) Uptake of new and regenerated forms of nitrogen in primary productivity. Limnol Oceanogr 12:196-206

Eppley RW, Koeller P, Wallace GT (1978) Stirring influences the phytoplankton composition within enclosed columns of coastal sea water. J exp mar Biol Ecol 32:219-239

Eppley RW, Renger EH (1988) Nanomolar increase in surface layer nitrate concentration following a small wind event Deep Sea Res 35:1119-1126

Fennel W, Lass HU, Seifert T (1986) Some aspects of vertical and horizontal excursion of phytoplankton. Ophelia (Suppl) 4:55-62

Filipov DM (1968) Circulation and structure of waters in the Black Sea. Nauka, Moscow (in Russian)

Finenko ZZ (1978) Production in plant populations. In: Kinne O (ed) Marine ecology, Vol IV, Dynamics. John Wiley \& Sons, Chichester, p 13-88

Gallegos CL, Platt T, Harrison WG, Irwin B (1983) Photosynthetic parameters of Arctic marine phytoplankton: vertical variations and time scales of adaptation. Limnol Oceanogr $28: 628-708$

Ivanov AI (1965) Characters of the qualitative composition of the phytoplankton in the Black Sea. In: Studies of the plankton of the Black Sea and the Asov Sea. Naukova Dumka, Kiev, p 17-35 (in Russian)

Jakubenko VG, Esaulov SE (1992) Temporal and spatial hydrophysic variability in the central parts of the Black Sea cyclonic gyre. In: Vinogradov ME (ed) Ecosystem of the open Black Sea in winter. Institute of Oceanology, Moscow, p 13-21 (in Russian)

Jones KJ, Gowen RJ (1980) Influence of stratification and irra- diance regime on summer phytoplankton composition in coastal and shelf seas of the British Isles. Estuar coast Shelf Sci 30(6):557-567

Kana, TM, Glibert, PM (1987) Effect of irradiances up to 2000 $E \mathrm{~m}^{-2} \mathrm{~s}^{-1}$ on marine Synechococcus WH $7803-\mathrm{I}$. Growth, pigmentation, and cell composition. Deep Sea Res 34(4A): $479-495$

Klein P, Coste B (1984) Effects of wind-stress variability on nutrient transport into the mixed layer. Deep Sea Res 31: $21-37$

Krupatkina DK, Finenko ZZ, Shalapyonok AA (1991) Primary production and size-fractionated structure of the Black Sea phytoplankton in the winter-spring period. Mar Ecol Prog Ser 73:25-31

Legendre L (1981) Hydrodynamic control of marine phytoplankton production: the paradox of stability. In: Nihoul, JC (ed) Ecohydrodynamics. Elsevier, Amsterdam, p $191-197$

Lewis MR, Horne EPW, Cullen JJ, Oakey NS, Platt T (1984) Turbulent motion may control phytoplankton photosynthesis in the upper ocean. Nature 311:49-50

Marra J (1978) Phytoplankton photosynthetic response to vertical movement in a mixed layer. Mar Biol 46:203-208

Mashtakova GP, Roukhiyainen MI (1979) The seasonal dynamics of the phytoplankton. In: Biological productivity of the Black Sea. Naukova Dumka, Kiev, p 85-87 (in Russian)

MCDuff RE, Chisholm SW (1982) The calculation of in situ growth rates of phytoplankton populations from fractions of cells undergoing mitosis: a clarification. Limnol Oceanogr 27(4):783-788

Mikaelyan AS (1984) Diurnal variations of phytoplankton abundance in the north-eastern part of the Black Sea. PhD thesis, Institute of Oceanology, Moscow (in Russian)

Morozova-Vodyanitskaya NV (1954) The phytoplankton of the Black Sea, Part II. Tr Sevastop Biol Stn 2:11-99 (in Russian)

Nelson DM, Brand LE (1979) Cell division periodicity in 13 species of marine phytoplankton on a light:dark cycle. J Phycol 15:67-75

Nezlin NP, Zernova VV (1983) The seasonal variations of the phytoplankton in the north-eastern part of the Black Sea in 1978. In: Sorokin YuI, Vedernikov VI (eds) Seasonal variations of plankton in the Black Sea. Nauka, Moscow, p 6-12 (in Russian)

Nikolaev VP, Sasin VD (1992) Optical characteristics of the Black Sea in February-March, 1991. In: Vinogradov ME (ed) Ecosystem of the open Black Sea in winter. Institute of Oceanology, Moscow, p 29-37 (in Russian)

Olson RJ, Chisholm SW (1983) Effects of photocycles and periodic ammonium supply on three marine phytoplankton species. I. Cell division patterns. J Phycol 19:522-528

Olson RJ, Vaulot D. Chısholm SW (1986) Effect of environmental stresses on the cell cycle of two marine phytoplankton species. Plant Physiol 80:189-198

Ovchinnikov IM, Moskalenko LV, Popov YuI, Serditenko VV (1991) Some peculiarities of the winter hydrological structure in the Black Sea. In: Vinogradov ME (ed) Changes in ecosystem of the Black Sea. Nauka, Moscow, p 8-25 (in Russian)

Ovchinnikov IM. Popov YuI (1990) Formation of the cold intermediate layer in the Black Sea under extremely winter conditions. Tr. Gos Okeangr Inst 190:132-151 (in Russian)

Pahl-Wostl C, Imboden DM (1990) DYPHORA - a dynamic model for the rate of photosynthesis of algae. J Plankton Res 12(6):1207-1221 
Post AF, Dubinsky Z, Wyman K, Falkowski PG (1984) Kinetics of light intensity adaptation in a marine plankton diatom. Mar Biol 83:231-238

Ratkova TN, Kopylov AI, Sazhin AF, Flint MV (1989) Accumulation of diatoms Nitzschia spp. in the cold intermed ate layer of the Black Sea. In: Vinogradov ME, Flint MV (eds) Structure and productivity characteristics of the planktonic communities of the Black Sea. Nauka, Moscow, p 38-52 (in Russian)

Sambrotto RN, Niebauer HJ, Goering JJ, Iverson RL (1986) Relationships among vertical mixing, nitrate uptake, and phytoplankton growth during the spring bloom in the southeast Bering Sea middle shelf Cont Shelf Res 5(1/2): $161-198$

Sorokin Jul, Sukhomlin AV, Sorokina OV (1992) Phytoplankton primary production in the Black Sea in winter/early spring, 1991 In: Vinogradov ME (ed) Ecosystem of the open Black Sea in winter lnstitute of Oceanology, Moscow, p 72-76 (in Russian)

Steele JH (1959) The quantitative ecology of marine phytoplankton. Biol Rev 34:129-158

Stolbova NG, Vedernikov VI, Mikaelyan AS (1982) Diurnal cell-division rhythm in dinoflagellates from the Black Sea. Oceanology 22(3):365-369

Strathmann RR (1967) Estimating the organic carbon content of phytoplankton from cell volume or plasma volume. Limnol Oceanogr 12(13):411-418

Strickland JDH, Eppley RW, Rojas de Mendiola B (1969) Phytoplankton populations, nutrents and photosynthesis in Peruvian coastal waters. Bull Inst mar Peru 2(1): $1-45$

Sukhanova IN, Belyaeva TV (1980) Species composition, distribution and diurnal variations of phytoplankton of the Black Sea in October 1978. In: Vinogradov ME (ed) Pelagic ecosystem of the Black Sea. Nauka, Moscow, p $65-91$ (in Russian)

Sukhanova IN, Georgieva LV, Mikaelyan AS, Sergeeva OM (1987) Phytoplankton of the open waters of the Black Sea in late spring season. In: Vinogradov ME (ed) Modern state of the Black Sea ecosystem. Nauka, Moscow, p $86-96$ (in Russian)

This article was submitted to the editor
Sukhanova IN, Mikaelyan AS, Georgieva LV (1991a) Spatıal distribution and temporal variations of phytoplankton in the Black Sea (March-April 1988) during the spring bloom period. In: Tsyban AV (ed) Studies of phytoplankton using monitoring system in the Baltic Sea and other seas of the USSR. Gidromet, Moscow, p 135-152 (in Russian)

Sukhanova IN, Pogosyan Sl. Vshivtsev VS (1991b) Temporal varlations of the populations structure of the mass species of phytoplankton in spring blooming. In: Vinogradov ME (ed) Changes in ecosystem of the Black Sea. Nauka, Moscow, p 117-127 (in Russian)

Sverdrup HU (1953) On conditions for the vertical blooming of phytoplankton. J Cons perm int Explor Mer 18:287-295

Swift E, Durbin EG (1972) The phased division and cytological characteristics of Pyrocystis spp. can be used to estimate doubling times of the populations in the sea. Deep Sea Res 19:189-198

Vedernikov VI (1991) Distribution of primary production and chlorophyll in the Black Sea in spring and summer In: Vinogradov ME (ed) Changes in ecosystem of the Black Sea. Nauka, Moscow, p 128-147 (in Russian)

Venrick EL (1978) How many cells to count? In: Sournia IA (ed) Phytoplankton manual. UNESCO, Paris, p 167-180

Videau C, Partensky F (1990) Variability in the growth characteristics of Gymnodinium of. nagasakiense (Dinophyceae) and its consequences on the determination of in situ growth rates. J exp mar Biol Ecol 142:169-182

Weiler CS, Chisholm SW(1976) Phased cell division in natural populations of marine dinoflagellates from shipboard cultures. J exp mar Biol Ecol 25(3):239-247

Yamazaki $H$, Kamykowski $D$ (1991) The vertical trajectories of motile phytoplankton in a wind-mixed water column. Deep Sea Res 38(2A):219-243

Yentsch CS (1981) Vertical mixing, a constraint to primary production: an extension of the concept of an optimal mixing zone. In: Nihoul JC (ed) Ecohydrodynamics. Elsevier, Amsterdam

Zernova VV (1981) Seasonal changes in species structure of phytocene in the north-eastern part of the Black Sea. In: Semina GI (ed) Ecology of marine phytoplankton. Institute of Oceanology, Moscow, p 43-64 (in Russian)

Manuscript first received: July 5, 1993

Revised version accepted: April 12, 1995 